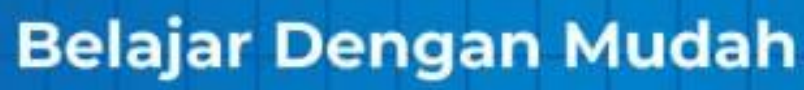 APLIKASI KOMPUTER \\ MYOB ACCOUNTING V.18}

(Mind Your Own Business Accounting)

MYOB (Mind Your Own Business Accounting) adalah sebuah program Aplikasi akuntansi yang digunakan untuk mengotomatisasikan pembukuan secara lengkap, cepat dan akurat, dengan sejumlah fasilitas, yaitu pemasukkan daftar akun, pengaturan (setup), mengelola bank, pelanggan, pemasok, produk sampai pada laporan keuangan seperti neraca, laba rugi, arus kas, persediaan dan sebagainya. Buku "Belajar dengan mudah Aplikasi Komputer MYOB Accounting $V_{.18}$ " ini disusun untuk menyelesaikan kasus akuntansi terutama penyajian dan pelaporan keuangan secara efektif dan efisien.

Pendekatan bukti transaksi digunakan sebagai upaya agar buku ini mendekati kegiatan dan permasalahan akuntansi secara nyata. Buku ini membahas mengenai settingan awal MYOB, saldo awal MYOB, seting pajak, Pencatatan transaksi menggunakan MYOB, Mencetak laporan, jurnal pembalik dan proses tutup buku pada akhir tahun. Pada bab akhir akan diberikan satu kasus perusahaan yang dapat digunakan untuk latihan lebih lanjut. Semoga buku ini dapat mempermudah proses penyusunan laporan keuangan.

Buku ini juga sudah menerapkan Stadar Akuntansi Keuangan (SAK) ETAP yang berlaku untuk perusahaan Mikro, Kecil dan Menengah (UMKM)

\section{Belajar Dengan Mudah}

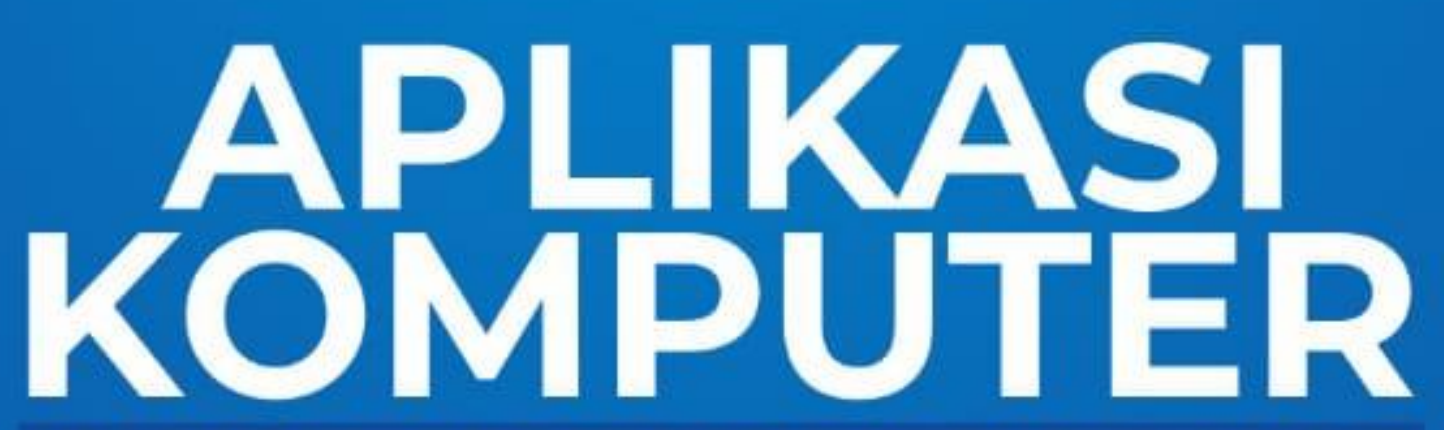
MYOB ACCOUNTING V.18

(Mind Your Own Business Accounting)

Agus Dwi Atmoko, SE, MM

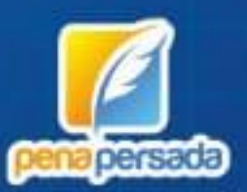




\section{BELAJAR DENGAN MUDAH \\ APLIKASI KOMPUTER \\ MYOB ACCOUNTING V.18 \\ (Mind Your Own Business Accounting)}

AGUS DWI ATMOKO, SE, MM

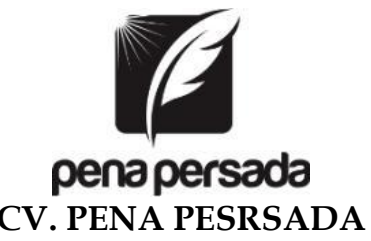




\title{
BELAJAR DENGAN MUDAH \\ APLIKASI KOMPUTER \\ MYOB ACCOUNTING V.18 \\ (Mind Your Own Business Accounting)
}

\author{
Penulis : \\ Agus Dwi Atmoko, SE, MM \\ ISBN : 978-623-6688-73-1 \\ Design Cover : \\ Retnani Nur Briliant \\ Layout : \\ Hasnah Aulia \\ Penerbit CV. Pena Persada \\ Redaksi : \\ Tengah \\ Email : penerbit.penapersada@gmail.com \\ Website : penapersada.com \\ Phone : (0281) 7771388 \\ Anggota IKAPI \\ All right reserved \\ Cetakan pertama : 2020
}

Jl. Gerilya No. 292 Purwokerto Selatan, Kab. Banyumas Jawa

Hak cipta dilindungi oleh undang-undang.

Dilarang memperbanyak karya tulis ini dalam bentuk dan cara apapun tanpa ijin penerbit 


\section{KATA PENGANTAR}

Buku ini berisi tentang hasil dari permasalahan yang penulis bahas, belajar dengan mudah komputer akuntansi menggunakan program MYOB Accounting Versi 18. Buku ini membahas bagaimana menggunakan MYOB Accounting Versi 18 mulai dari memasukan data perusahaan dan memasukan tiap transaksi beserta latihan soal serta studi kasus pada perusahaan manufaktur untuk menghasilkan laporan keuangan. Dengan menggunakan buku ini diharapkan mempermudah pembaca dalam belajar praktek komputer akuntansi menggunakan program MYOB Accounting Versi 18.

Semoga buku ini dapat memberikan wawasan yang lebih luas dan menjadi sumbangan pemikiran kepada pembaca. Saya sadar bahwa buku ini masih banyak kekurangan dan jauh dari sempurna. untuk itu, kepada para pembaca kami minta masukannya demi perbaikan pembuatan buku ini di masa yang akan datang dan mengharapkan kritik dan saran dari para pembaca.

Semoga karya ini dapat memberikan suatu manfaat bagi pembaca dan semua pihak yang terlibat dalam penulisan Belajar dengan mudah Aplikasi Komputer Myob Accounting Versi 18.

Penulis 


\section{DAFTAR ISI}

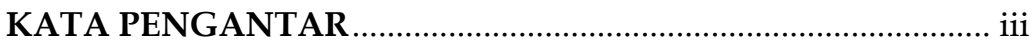

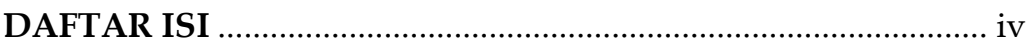

BAB I MYOB ACCOUNTING

A. Pengertian Myob Accounting ................................................ 1

1. MYOB Accounting V.18 .............................................. 1

2. Membuat Data Perusahaan ............................................. 1

B. Membuka Data Perusahaan ................................................. 3

1. Memasukan Data Perusahaan........................................... 3

2. Mengisi data Perusahaan .................................................. 4

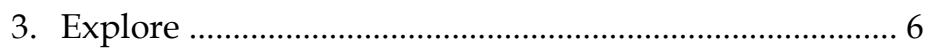

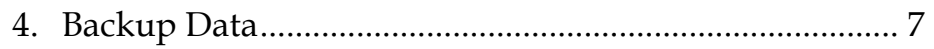

BAB II MEMBUAT DATA PERUSAHAAN

A. Membuat Data Perusahaan Baru............................................ 11

B. Memasukan Data Baru ............................................................ 21

C. Mengisi Data Perusahaan...................................................... 25

BAB III MENCATAT SALDO AWAL

A. Mencatat Saldo Awal ............................................................ 81

B. Membuat Daftar Pelanggan ………………......................... 82

C. Mencatat Saldo Awal Piutang .............................................. 87

D. Mencatat Saldo Awal Hutang ................................................ 87

E. Mencatat Persediaan Barang Dagang ………....................... 97

BAB IV JURNAL

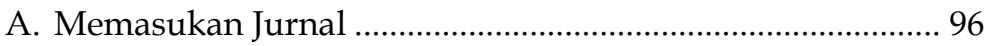

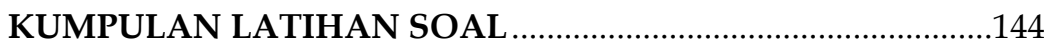

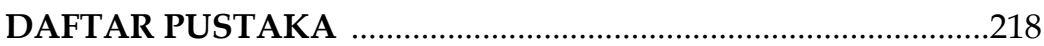




\section{BAB I \\ MYOB ACCOUNTING}

\section{A. Pengertian Myob Accounting}

\section{MYOB Accounting V.18}

MYOB merupakan kepanjangan dari Mind Your Own Bussiness, yang berarti bagaimana cara kita untuk mengelola transaksi keuangan kita sendiri. Secara umum fungsi dari MYOB sama dengan program akuntansi lainnya, yaitu mengerjakan siklus akuntansi dan menghasilkan laporan keuangan serta laporan lain yang disediakan oleh MYOB Accounting.

\section{Membuat Data Perusahaan}

Program MYOB dapat langsung dibuka melalui desktop komputer Anda apabila telah terinstal sebelumnya dengan benar. Caranya adalah dengan mengklik double atau tekan Enter pada icon MYOB seperti gambar berikut :

Gambar 1.1 Membuka program MYOB Accounting Plus V18

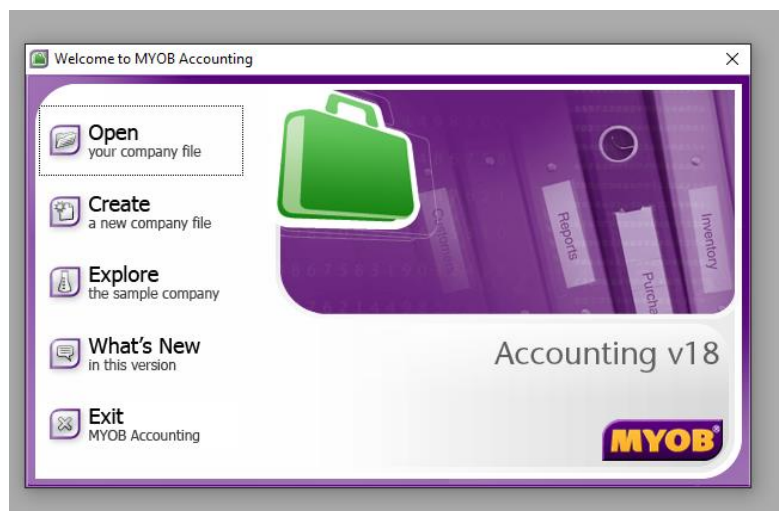

Gambar 1.1 Jendela Welcome to MYOB Accounting 


\section{Keterangan :}

- Open : Membuka Data Perusahaan yang telah dibuat sebelumnya

- Create : Membuat Data baru perusahaan

- Explore : Melihat contoh data perusahaan yang telah disediakan oleh MYOB

- What's New : Melihat informasi tentang fasilitas baru yang disediakan MYOB

- Exit : Keluar dari program MYOB

\section{Membuka Data Perusahaan}

Untuk membuka data perusahaan yang telah dibuat sebelumnya, yaitu dengan langkah-langkah sebagai berikut : 1. Klik OPEN. Selanjutnya akan muncul kotak dialog seperti berikut, klik tanda panah pada kotak Look in untuk mencari lokasi penyimpanan file.

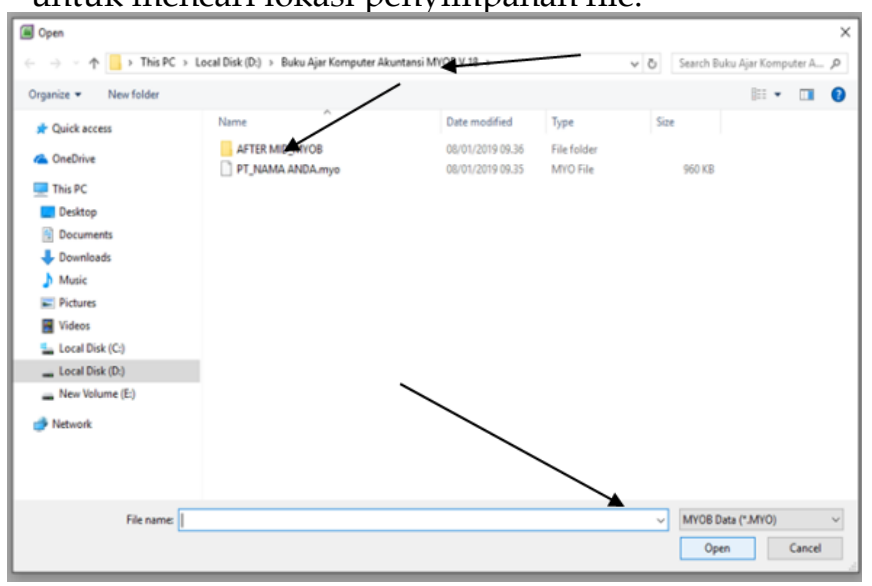

Kemudian Klik nama file nya, lalu klik Open. Maka akan muncul seperti berikut: 


\section{Enter your User ID and Password}

If this is the first time you are opening your file since upgrading, please type "Administrator" in the User ID field and enter your master password if you have one.

User ID: Administrator

Password:

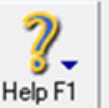

Kemudian Klik ok

2. Pilih Opsi yang ketiga, kemudian klik Continue

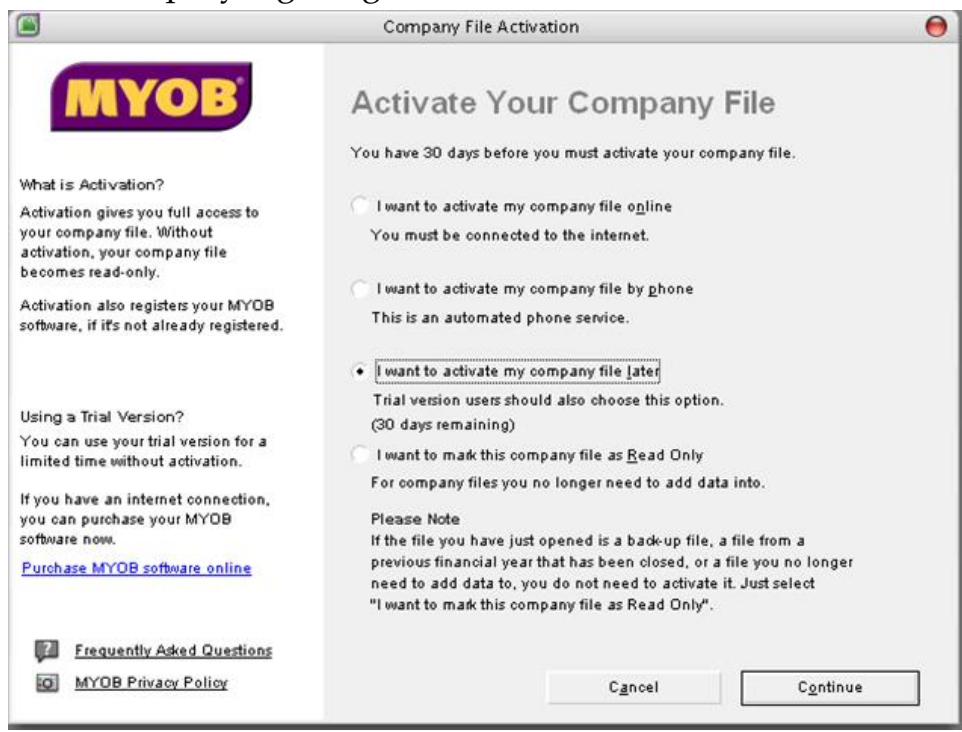

3. Klik Ok - No

\section{B. Membuka Data Baru Perusahaan}

1. Memasukan Data Perusahaan

Klik Create a New company file, maka akan tampil jendela informasi a New Company file Assistant. 


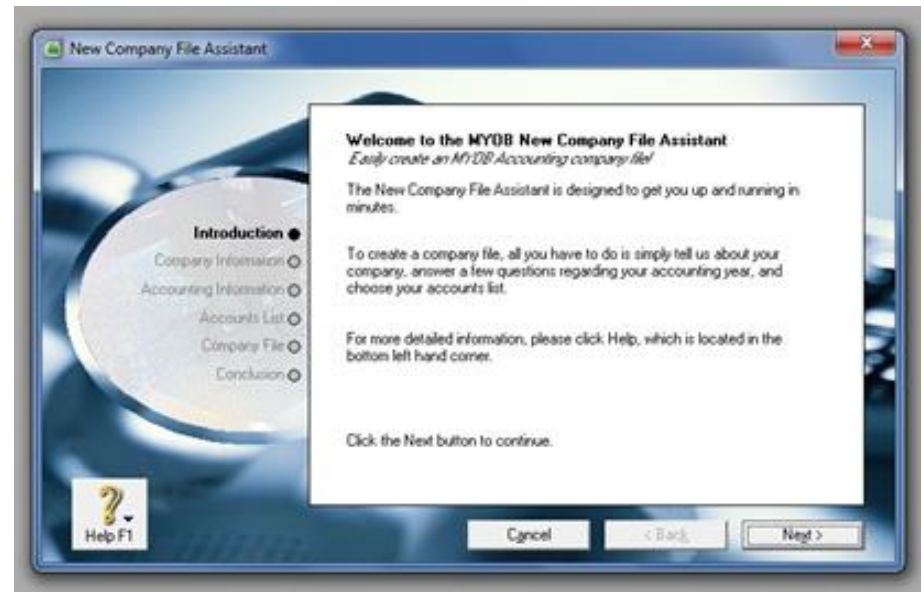

Jendela New Company File Asisstant

Klik Next, untuk melanjutkan ke tahap pengisian data perusahaan, Isi data perusahaan.

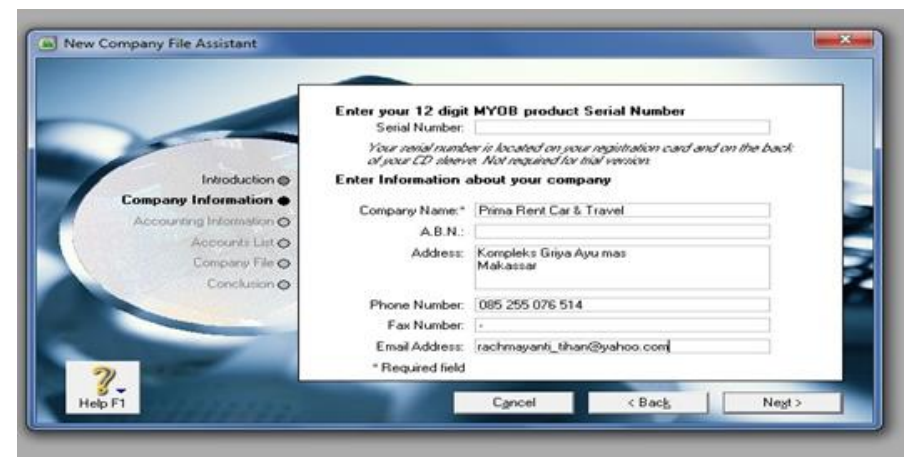

2. Mengisi data Perusahaan

Setelah selesai, Klik Next. Berikutnya anda akan mengisi periode akuntansi yang akan digunakan perusahaan. 


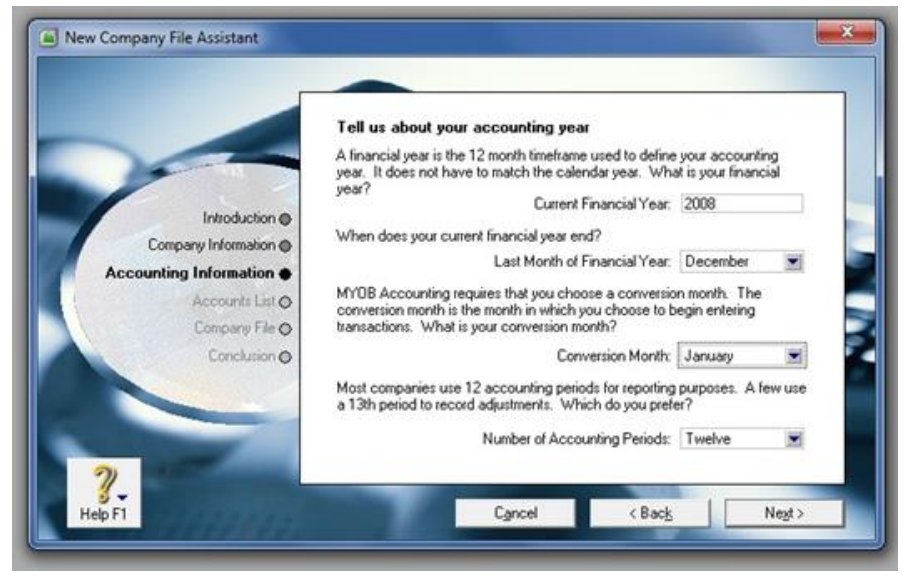

Mengisi periode akuntansi

Ket : - Current Financial Year : Isi tahun buku pembukuan

- Last Month of Financial Year : Akhir Periode pembukuan

- Conversion Month : Awal Periode Pembukuan

- Number of Accounting Periode : Jumlah Periode

a. Klik Next untuk menampilkan informasi periode akutansi sesuai dengan pengaturan yang telah dilakukan. Baca kembali informasi yang ditampilkan, jiak terdapat kesalahan klik tombol Back untuk memperbaikinya, jika tidak langsung klik Next

b. b. Pada kotak pilihan Build Your Account List, anda tentukan cara pembuatan daftar akun yang akan digunakan. MYOB menyediakan 3 pilhan pembukuan daftar akun yaitu :

1) I Would like to start with one of the list provided by MYOB Accounting, artinya Anda akan menggunakan daftar akun yang telah disediakan oleh MYOB

2) I Would like to import to list of account provided by my accountant after I'm done creating my company file. Artinya anda akan mengimpor daftar akun dari file lain. 
3) I Would like to build my own accounts list once I begin using MYOB, artinya anda akan membuat sendiri daftar akun secara langsung. Pada Kasus kali ini Klik pilihan Kedua. Lalu klik Next

4) Berikutnya akan tampil jendela informasi lokasi penyimpanan file. Standarnya MYOB akan menyimpan file didalam drive C: $\backslash$ myob18ED $\backslash$ Prima Rent Car\&Travel.myo. jika ingin mengubah lokasi penyimpanan file klik tombol Change, jika tidak langsung klik Next.

5) Selanjutnya MYOB akan memproses data perusahaan yang telah kita masukkan.

Setelah proses selesai akan tampil informasi Congratulations! Artinya bahwa pembuatan file perusahaan sukses. untuk masuk ke menu utama MYOB klik Commad Center

3. Menu utama MYOB Accounting V18

\section{Informasi Pembuatan file Sukses}

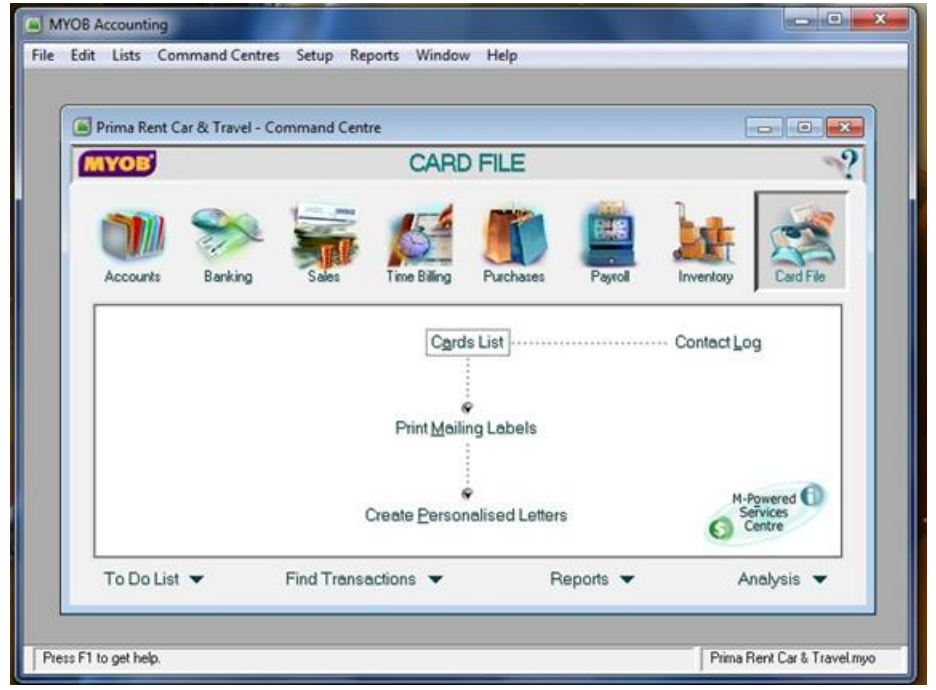


4. Explore

MYOB menyediakan contoh data perusahaan yang telah selesai dibuat. Klik Explore, kemudian klik Ok. Maka akan tampil contoh data perusahaan yang disediakan MYOB 18.

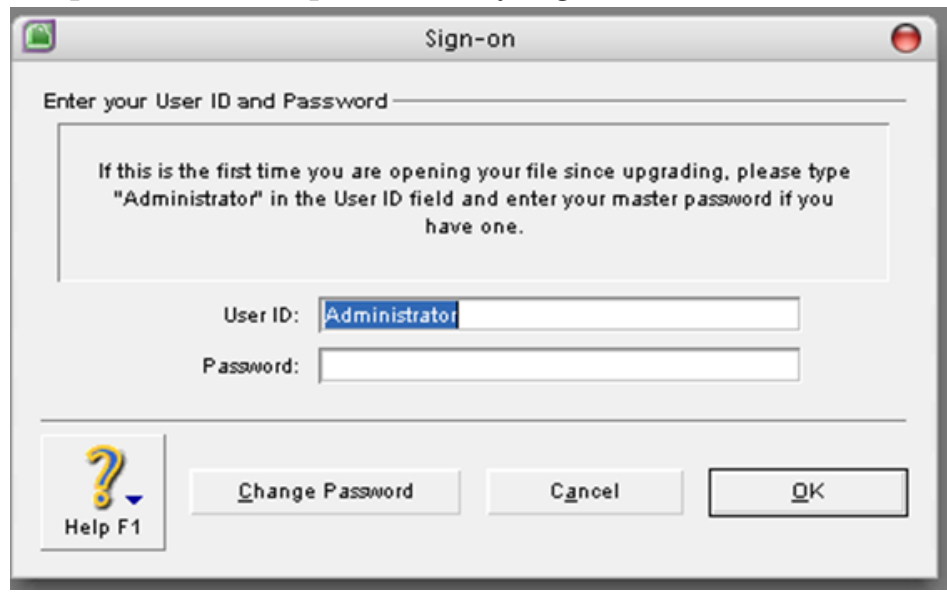

Menutup Program MYOB (Exit)

Untuk menutup program MYOB klik Exit.

5. Backup Data

Membuat Backup Data

Backup data adalah kegiatan menyimpan file data dalam bentuk ZIP dan meletakkannya di folder BACKUP.

Tujuan dari backup data adalah untuk mengantisipasi terjadinya masalah mengenai keamanan dan kehilangan data, agar file memiliki cadangan apabila sewaktu-waktu terjadi kerusakan atau kehilangan data yang telah dibuat dalam MYOB. Jadi apabila data atau file perusahaan tibatiba rusak atau hilang, maka pengguna tidak perlu mengentri/memasukkan data dari awal lagi. Backup data dilakukan apabila pengguna ingin meninggalkan atau menutup program MYOB. 
Berikut ini adalah langkah-langkah melakukan BackUp Data :

a. Klik File - Backup

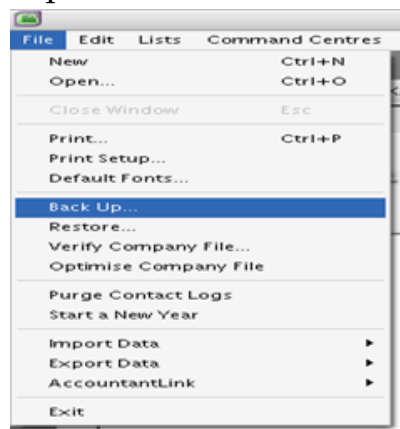

b. Kemudian muncul kotak dialog seperti berikut :

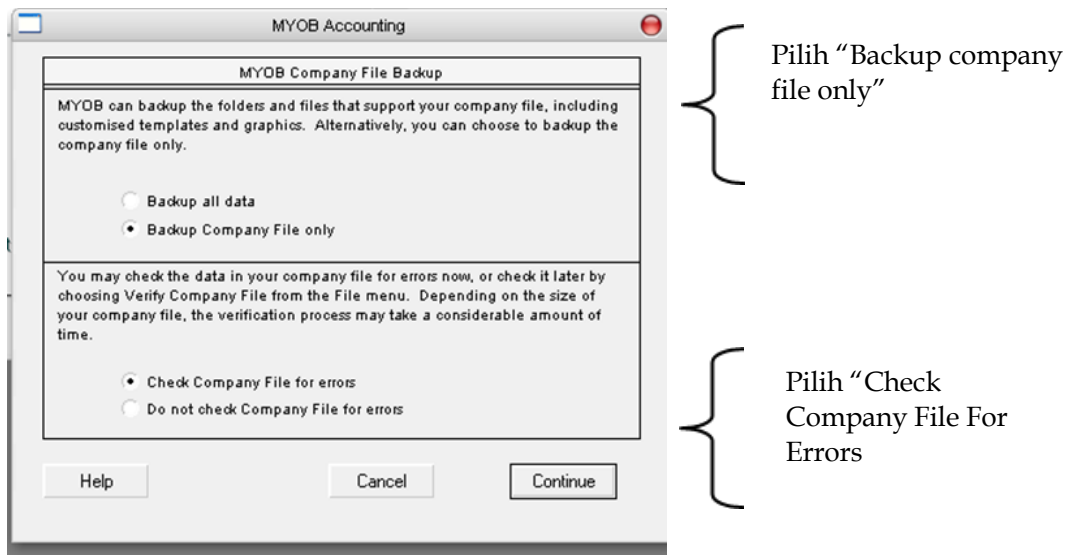

c. Klik tombol Continue. Setelah itu, biarkan proses berjalan beberapa saat sampai muncul tampilan direktori penyimpanan data.

d. Pilihlah media penyimpanan yang akan digunakan melalui kotak Save In, misalnya akan disimpan pada Flash disk atau $\mathrm{CD}$ atau media penyimpanan lainnya. Contoh berikut adalah menyimpan atau membackup data ke dalam Draft D. 


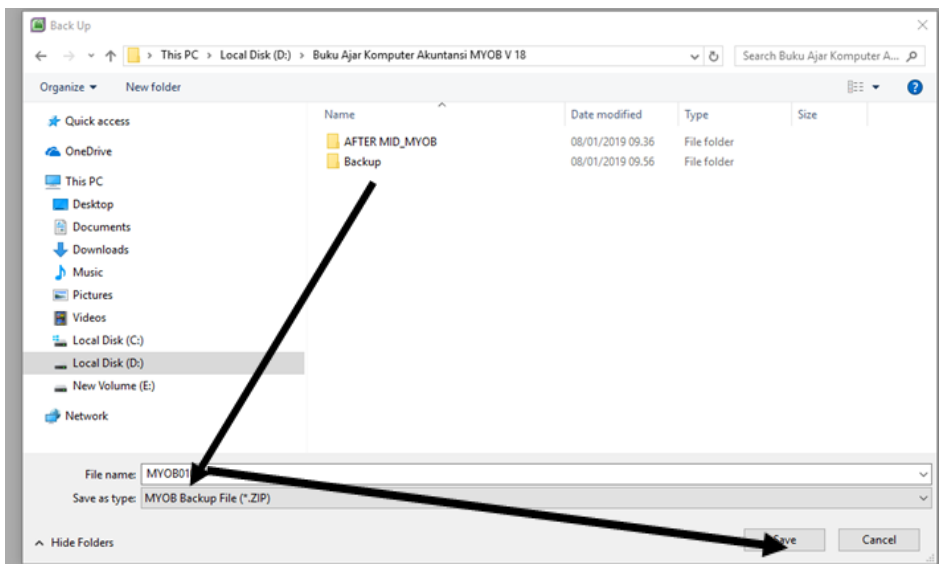

e. Kemudian Ubah nama file, selanjutnya Klik Save.

f. Tunggu proses selesai, maka data Anda telah di backup ke Draft D.

1) Memanggil Kembali Data Backup (Restore)

Restore adalah kegiatan memanggil kembali data yang tersimpan dalam bentuk ZIP yang merupakan hasil backup.

Sesuai dengan fungsi backup data yaitu mengantisipasi kerusakan atau kehilangan data, maka apabila terjadi hal tersebut kita dapat membuka file backup data kita dalam bentuk ZIP. Adapun langkah-langkah restore sebagai berikut :

(1) Klik File - Restore

(2) Kemudian Klik No

(3) Setelah itu, muncul kotak dialog untuk mencari lokasi penyimanan file backup data yang telah dibuat. Klik tanda panah pada kolom Look in. Kemudian klik file backup yang dimaksud, lalu klik Open.

(4) MYOB akan mengkonfirmasi penyimpanan ulang file backup tersebut. Pilih lokasi penyimpanan dan nama file yang sesuai dengan kebutuhan Anda. Kemudian klik Save.

(5) Tunggu hingga proses backup data selesai. 


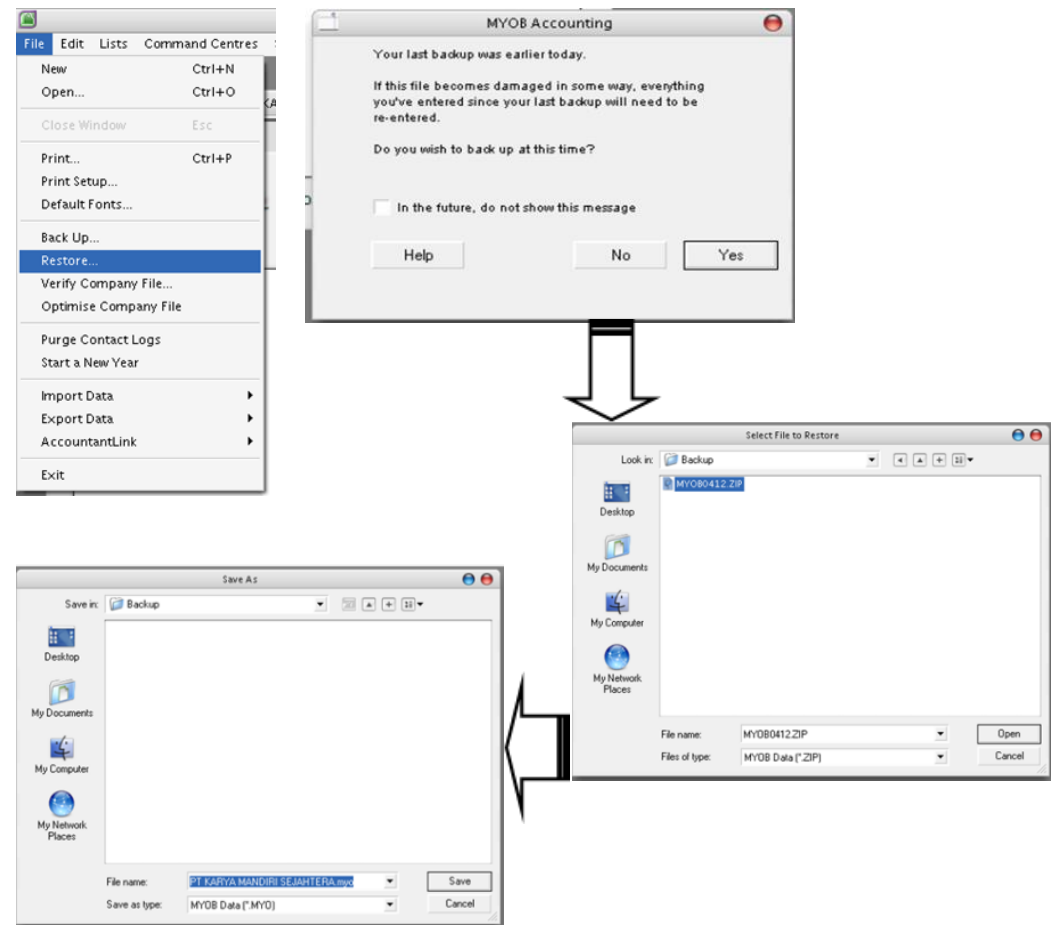




\section{BAB II \\ DATA PERUSAHAAN}

\section{A. Membuat Data Perusahaan}

Langkah-langkah untuk membuat data baru perusahaan adaalah :

1. Mengisi identitas perusahaan dan kebijakan akuntansi perusahaan

2. Membuat daftar akun dan import data akun

3. Mengatur link untuk akun

4. Menyempurnakan daftar akun

5. Membuat link untuk pajak yang digunakan

6. Membuat daftar nama pelanggan dan pemasok

7. Menginput saldo awal Neraca Saldo, saldo Piutang, dan saldo Hutang

8. Membuat Daftar Persediaan Barang

Berikut ini adalah contoh perusahaan yang bergerak dalam bidang perdagangan.

\section{DATA AKUNTANSI \\ PT NAMA ANDA}

Account Lists

\begin{tabular}{|c|c|c|}
\hline Nomor & Nama Assets & $\begin{array}{l}\text { Keterangan, digunakan } \\
\text { untuk mencatat: }\end{array}$ \\
\hline & Current Assets & \\
\hline $1-1110$ & Cash in bank & $\begin{array}{l}\text { Penarikan dan penyetoran kas } \\
\text { di bank }\end{array}$ \\
\hline $1-1120$ & Petty cash & $\begin{array}{l}\text { Pengeluaran dan penerimaan } \\
\text { kas kecil }\end{array}$ \\
\hline $1-1130$ & Undesposited Funds & Penerimaan kas sementara \\
\hline $1-1210$ & Accounts Receivable & $\begin{array}{l}\text { Penambahan dan pengurang- } \\
\text { an piutang dagang }\end{array}$ \\
\hline $1-1220$ & Allowance for Doubtful & $\begin{array}{l}\text { Penyisihan atau cadangan ke- } \\
\text { rugian piutang }\end{array}$ \\
\hline $1-1310$ & Debt & $\begin{array}{l}\text { Penambahan dan pengurang- } \\
\text { an barang dagangan }\end{array}$ \\
\hline
\end{tabular}




\begin{tabular}{|c|c|c|}
\hline $1-1320$ & Merchandise Inventory & $\begin{array}{l}\text { Penambahan dan pengurang- } \\
\text { an perlengkapan }\end{array}$ \\
\hline $1-1410$ & Supplies & $\begin{array}{l}\text { Penambahan dan pengurang- } \\
\text { an uang muka sewa }\end{array}$ \\
\hline $1-1420$ & $\begin{array}{l}\text { Preparied Rent } \\
\text { Preparied Insurance }\end{array}$ & $\begin{array}{l}\text { Penambahan dan pengurang- } \\
\text { an uang muka asuransi }\end{array}$ \\
\hline $1-2100$ & $\begin{array}{l}\text { Long Term Invesment } \\
\text { Stock Investment }\end{array}$ & $\begin{array}{l}\text { Penambahan dan penguranan } \\
\text { investasi saham }\end{array}$ \\
\hline $1-3100$ & Fixed Assets & $\begin{array}{l}\text { Penambahan dan pengurang- } \\
\text { an nilai tanah }\end{array}$ \\
\hline $1-3210$ & Land & $\begin{array}{l}\text { Penambahan dan pengurang- } \\
\text { an nilai bangunan }\end{array}$ \\
\hline $1-3220$ & Building at Cost & $\begin{array}{l}\text { Penambahan dan pengurang- } \\
\text { an akum. Dep Bangunan }\end{array}$ \\
\hline $1-3310$ & Building Accum Dep & $\begin{array}{l}\text { Penambahan dan pengurang- } \\
\text { an nilai kendaraaan/ }\end{array}$ \\
\hline $1-3320$ & Vehicle at Cost & $\begin{array}{l}\text { Penambahan dan pengurang- } \\
\text { an akum. Dep Kendaraan }\end{array}$ \\
\hline $1-3410$ & Vehicle Accum Dep & $\begin{array}{l}\text { Penambahan dan pengurang- } \\
\text { an nilai peralatan }\end{array}$ \\
\hline $1-3420$ & $\begin{array}{l}\text { Equipment at Cost } \\
\text { Equipment Accum Dep } \\
\text { Liabilities } \\
\text { Current Liabilities }\end{array}$ & $\begin{array}{l}\text { Penambahan dan pengurang- } \\
\text { an akum. Dep peralatan }\end{array}$ \\
\hline $2-1110$ & Master Card & $\begin{array}{l}\text { Penambahan dan pengurang- } \\
\text { an utang kredit card }\end{array}$ \\
\hline $2-1210$ & Account Payable & $\begin{array}{l}\text { Penambahan dan pengurang- } \\
\text { an utang dagang }\end{array}$ \\
\hline $2-1220$ & Devident Payable & $\begin{array}{l}\text { Penambahan dan pengurang- } \\
\text { an utang deviden }\end{array}$ \\
\hline $2-1230$ & PPN Payable & $\begin{array}{l}\text { Penambahan dan pengurang- } \\
\text { an utang PPN }\end{array}$ \\
\hline $2-1240$ & Income Tax Payable & $\begin{array}{l}\text { Penambahan dan pengurang- } \\
\text { an utang PPh Badan }\end{array}$ \\
\hline $2-1310$ & PPN Outcome & $\begin{array}{l}\text { Penambahan dan pengurang- } \\
\text { an PPN Keluaran }\end{array}$ \\
\hline $2-1320$ & PPN Income & $\begin{array}{l}\text { Penambahan dan pengurang- } \\
\text { an PPN Masu-kan }\end{array}$ \\
\hline $2-2100$ & $\begin{array}{l}\text { Long Term Liabilities } \\
\text { Bank Mandiri Loan }\end{array}$ & $\begin{array}{l}\text { Penambahan dan pengurang- } \\
\text { an utang jk. Panjang }\end{array}$ \\
\hline
\end{tabular}




\begin{tabular}{|c|c|c|}
\hline $3-1100$ & $\begin{array}{l}\text { Equity } \\
\text { Common Stock }\end{array}$ & $\begin{array}{l}\text { Penambahan dan penguranan } \\
\text { modal saham biasa }\end{array}$ \\
\hline $3-1200$ & Prefered Stocks & $\begin{array}{l}\text { Penambahan dan pengurang- } \\
\text { an modal saham preferen. }\end{array}$ \\
\hline $3-1300$ & Agio (Disagio) & $\begin{array}{l}\text { Penambahan dan penguranan } \\
\text { agio atau disagio saham }\end{array}$ \\
\hline $3-3000$ & Income Summary & $\begin{array}{l}\text { Akun sementara ikhtisar laba- } \\
\text { rugi }\end{array}$ \\
\hline $3-8000$ & Retained Earnings & $\begin{array}{l}\text { Penambahan dan peng- } \\
\text { urangan laba ditahan }\end{array}$ \\
\hline $3-9000$ & Current Year Earnings & $\begin{array}{l}\text { Penambahan dan pengurang- } \\
\text { an laba periode berjalan }\end{array}$ \\
\hline $4-1100$ & $\begin{array}{l}\text { Income } \\
\text { Sales of Merchandise }\end{array}$ & $\begin{array}{l}\text { Penambahan dan pengurang- } \\
\text { an penjualan }\end{array}$ \\
\hline $4-2100$ & Freight Collected & $\begin{array}{l}\text { Penambahan pungutan biaya } \\
\text { transport penjualan }\end{array}$ \\
\hline $4-2200$ & Late Fees Collected & $\begin{array}{l}\text { Penambahan pungutan denda } \\
\text { pembayaran piutang }\end{array}$ \\
\hline & Cost Of Sales & \\
\hline $5-1100$ & Cost Of Good Sold & $\begin{array}{l}\text { Penambahan dan pengurang- } \\
\text { an harga pokok penjualan }\end{array}$ \\
\hline $5-2000$ & Freight Paid & $\begin{array}{l}\text { Penambahan beban transport } \\
\text { pembelian }\end{array}$ \\
\hline $5-3000$ & Purchase Discount & $\begin{array}{l}\text { Penambahan potongan pemb- } \\
\text { elian }\end{array}$ \\
\hline & $\begin{array}{l}\text { Operating Expenses } \\
\text { Advertising \& Promotion }\end{array}$ & \\
\hline $6-1100$ & Advertising Expense & Penambahan beban iklan \\
\hline $6-1200$ & In-store Promotion Expense & $\begin{array}{l}\text { Penambahan beban promosi } \\
\text { di dalam toko }\end{array}$ \\
\hline & $\begin{array}{l}\text { General And Administrative } \\
\text { Expenses }\end{array}$ & \\
\hline $6-2100$ & Utility expense & $\begin{array}{l}\text { Penambahan beban utiliti } \\
\text { (listrik dan air) }\end{array}$ \\
\hline $6-2200$ & Telephone expense & Penambahan beban telepon \\
\hline $6-2300$ & Rent expense & Penambahan beban sewa \\
\hline $6-2400$ & Supplies Expense & $\begin{array}{l}\text { Penambahan beban per- } \\
\text { lengkapan }\end{array}$ \\
\hline $6-2500$ & $\begin{array}{l}\text { Maintenance and Repair Ex- } \\
\text { penses }\end{array}$ & $\begin{array}{l}\text { Penambahan beban pe- } \\
\text { meliharaan \& reparasi }\end{array}$ \\
\hline $6-2600$ & Bad Debts expense & Penambahan beban kerugian \\
\hline
\end{tabular}




\begin{tabular}{|c|c|c|}
\hline & & penghapusan piutang \\
\hline $6-2700$ & Depreciation expense & $\begin{array}{l}\text { Penambahan beban depresiasi } \\
\text { aktiva tetap }\end{array}$ \\
\hline $6-2800$ & Insurance expense & Penambahan beban asu-ransi \\
\hline $6-2900$ & Late Fees Paid & $\begin{array}{l}\text { Penambahan beban den-da } \\
\text { pembayaran }\end{array}$ \\
\hline $6-2950$ & Sales Discount & $\begin{array}{l}\text { Penambahan potongan penj- } \\
\text { ualan }\end{array}$ \\
\hline $6-3100$ & $\begin{array}{l}\text { Wages \& SalariesOther Inco- } \\
\text { me } \\
\text { Other Income }\end{array}$ & $\begin{array}{l}\text { Penambahan beban up-ah dan } \\
\text { gaji }\end{array}$ \\
\hline $8-1000$ & Interest Income & $\begin{array}{l}\text { Penambahan pendapatan bu- } \\
\text { nga }\end{array}$ \\
\hline $8-2000$ & Devident Income & $\begin{array}{l}\text { Penambahan pendapatan } \\
\text { deviden }\end{array}$ \\
\hline $\begin{array}{l}8-3000 \\
8-4000\end{array}$ & $\begin{array}{l}\text { Gain (loss) on sale of Fixed } \\
\text { Assets }\end{array}$ & $\begin{array}{l}\text { Penambahan laba dari } \\
\text { penjualan aktiva tet-ap }\end{array}$ \\
\hline & $\begin{array}{l}\text { Gain (loss) on sale of Stocks } \\
\text { Other Expenses }\end{array}$ & $\begin{array}{l}\text { Penambahan laba dari } \\
\text { penjualan saham }\end{array}$ \\
\hline $9-1000$ & Interest Expense & Penambahan beban bunga \\
\hline $9-2000$ & Bank Service Charge & $\begin{array}{l}\text { Penambahan beban se-rvice } \\
\text { bank }\end{array}$ \\
\hline 9-3000 & Income Tax Expense & $\begin{array}{l}\text { Penambahan beban pajak } \\
\text { penghasilan }\end{array}$ \\
\hline
\end{tabular}

\section{Identitas Perusahaan}

Nama Perusahaan : PT.Nama Anda

Tempat kedudukan : Jl. Wismoaji No. 18 Kutoarjo

No. Telp

:02745 642466 Fax. 0275642467

Akte Pendirian

: No. 2800 Tgl. 10 Maret 2005

Akte

: Perubahan Notaris Antonius Saputra, SH di Jakarta).

N.P.W.P

: No. 01.115.203.1.020.000 tanggal 01

April 2014

N.P.P.K.P

: No. 01.115.203.1.020.000 tanggal 15

Juni 2014 


\section{Bidang Usaha}

PT. Nama Anda adalah sebuah Perusahaan Dagang yang didirikan di Purworejo pada tanggal 15 Januari 2014 sampai sekarang. Berikut neraca saldo per 1 Desember 2019

\section{PT NAMA ANDA}

NERACA SALDO

PER 1 DESEMBER 2019

\begin{tabular}{|c|c|c|c|}
\hline No.akun & Nama Akun & Debet (Rp) & Kredit (Rp) \\
\hline 1.1101 & Cash on Hand & 252.000 .000 & -- \\
\hline 1.1102 & Cash in Bank & 769.000 .000 & -- \\
\hline 1.1201 & Account Receivable & 1.319.452.585 & -- \\
\hline 1.1202 & Allowance of Doubtful Debt & -- & 26.389 .052 \\
\hline 1.1300 & Inventory & 2.636 .960 .000 & -- \\
\hline 1.1400 & Office Supplies & & \\
\hline 1.1501 & Prepaid Insurance & & \\
\hline 1.1502 & Prepaid Rent & & \\
\hline 1.1601 & VAT In & & \\
\hline 1.1602 & Prepaid Tax Article 22 & & \\
\hline 1.2100 & Land & 1.050 .000 .000 & -- \\
\hline 1.2210 & Building & 875.000 .000 & -- \\
\hline 1.2220 & $\begin{array}{l}\text { Building Accumulated } \\
\text { Depreciation } \\
\end{array}$ & -- & 43.750 .000 \\
\hline 1.2310 & Car & 900.000 .000 & -- \\
\hline 1.2320 & $\begin{array}{l}\text { Car Accumulated } \\
\text { Depreciation }\end{array}$ & -- & 243.000 .000 \\
\hline 1.2410 & Equipment & 300.000 .000 & -- \\
\hline 1.2420 & $\begin{array}{l}\text { Equipment Accumulated } \\
\text { Depreciation }\end{array}$ & -- & 48.000 .000 \\
\hline 2.1100 & Account Payable & -- & 869.539 .000 \\
\hline 2.1301 & VAT Out & & \\
\hline 2.1302 & Tax Article 21 Payable & -- & 9.901 .768 \\
\hline
\end{tabular}

